\title{
Study on Melanized Shrimp Reveals Bacillus sp and Acinetobacter sp as Potential Sources for Bacterial Tyrosinase
}

\author{
T. Muthulakshmi*1, U. Sivakumar ${ }^{2}$, Ranjit Kumar Nadella ${ }^{1}$, V. Murugadas ${ }^{1}$, \\ S.S. Greeshma ${ }^{1}$ and M.M. Prasad ${ }^{1}$ \\ ${ }^{1}$ MFB Division, ICAR-Central Institute of Fisheries Technology, Willingdon Island, \\ Matsyapuri P.O., Cochin, Kerala, India 682029 \\ ${ }^{2}$ Department of Microbiology, Tamil Nadu Agricultural University, \\ Coimbatore, 641003, India \\ *Corresponding author
}

\section{A B S T R A C T}

\begin{tabular}{|l|}
\hline Ke y w o r d s \\
Tyrosinase, Phenol \\
oxidase, \\
Melanization, \\
Bacillus sp \\
\hline Article Info \\
\hline $\begin{array}{l}\text { Accepted: } \\
\text { 12 November } 2019 \\
\text { Available Online: } \\
\text { 10 December } 2019\end{array}$ \\
\hline
\end{tabular}

\section{Introduction}

Invertebrates such as shrimp lack advanced immune system and the immunity is dominated by innate immune responses. Prophenoloxidase system plays a major role in identification, sequestration and elimination of invading pathogens. Melanization, which is performed by phenoloxidase (PO) and controlled by the prophenoloxidase (proPO) activation cascade, plays an important role in the invertebrate immune system in allowing a rapid response to pathogen infection (Amparyup et al., 2013) 
Tyrosinase is an enzyme that belongs to oxidoreductase group first discovered by Schoenben while studying the oxidation in mushrooms in 1856. Since then it is reported in most of the plant tissues, fungi, actinomytes and bacteria. Different bacteria are known to produce tyrosinase, such as Streptomyces sp, Rhizobium, Pseudomonas putida, Bacillus thuringiensis, Marinomonas mediterranes, Ralstonia solanacearum, Cellulophaga thyroxidans (Whittager., 1995; Liu et al., 2004; Mc Mahon et al., 2007; Kahng et al., 2009; Sanchez-amat et al., 2010). Relationship of tyrosinases with the oxygen-binding and oxygen-transporting has been established (Dursewitz and Terwilliger., 1997; Decker and Terwilliger, 2000) by oxidizing monophenols to o-dihydroxyphenols and further to oquinones. This enzyme belongs to the polyphenoloxidases family mainly known for the defense (Amparyup et al., 2013), cuticle sclerotization and wound healing in crustaceans (Sugumaran, 1996, 1998).

Melanins are black or brown colored biopolymers biologically synthesized with the intermediate products viz., L-3, 4 dihydroxyphenyl alanine (L-Dopa), Dopaquinone and dopamine by melanin forming enzymes such as tyrosinase and laccase. Melanin is synthesized as dopachrome and is converted to melanin by non-enzymatic reactions. Melanin has inherent properties like absorption of UV radiation, metals, sound and also have anti-oxidant and semi-conductor properties thus are used in the production of complex biopolymers (EMPA. 2010).

Melanosis, also called as black spot, the enzymatic browning of phenolic compounds in shrimp is considered as a challenge in processing industry. Melanosis in shrimp is due to innate immune response prophenoloxidase system and bacterial conversion of the phenolic compounds into melanin with the help of phenoloxidase enzymes (Goncalves et al., 2016). Shrimp melanosis due to innate immune response is well studied (Cerenius and Soderhall, 1998, 2004; Sritunyalucksana et al., 1999). The shrimp pereopods were not reported to have PPO contrary to the carapace, cephalothorax pleopod and telson (Zamorano et al., 2009). The bacterial associated melanosis studies were done in the context of spoilage microbes (Qian et al., 2014; Charoensapsri et al., 2014). However, there is a paucity in data pertaining to melanised appendages where the proPO activity is minimum and the bacterial associated melanosis other than spoilage bacteria. The pereopod melanisation in the market shrimp might be due to the action of microbes. Hence, this present study of screening bacteria as a source for tyrosinase enzyme was undertaken in shrimp melanised appendages.

\section{Materials and Methods}

\section{Sample collection}

Penaeus vannamei with melanized appendages were procured from retail fish market of Ukkadam, Coimbatore, Tamil Nadu. The sampled shrimp were brought to the laboratory in chilled condition in an insulated box and processed for the isolation within four hours of the sampling.

\section{Isolation of tyrosinase producing bacteria}

The shrimp surface was sterilized with $70 \%$ alcohol and chitin shell was removed from the shrimp. Melanized appendages sampled from the shrimp were macerated and transferred to sterile tyrosinated saline $(0.1 \%$ tyrosine supplemented with normal physiological saline) used for isolation of tyrosinase producing bacteria. Composition of the media used for isolation for a litre of media includes tryptone $1 \%$, L-tyrosine $0.1 \%$, magnesium 
sulphate $0.025 \%$, potassium phosphate dibasic $0.05 \%, \mathrm{NaCl} 0.85 \%$, Agar $1.5 \%$ ). In the autoclave sterilized media, macerated melanized appendages were inoculated. Plates were incubated at room temperature for $48 \mathrm{~h}$. The colonies producing dark pigmentation were taken for further identification by biochemical tests (Leifson, 1963). Confirmation of potential tyrosinase producing ability was once again checked in positive and negative selection method.

\section{DNA isolation and 16S rRNA identification}

Potential tyrosinase producing isolates viz; TMA 7, TMA9, and TMA10 were selected for further identification. The total DNA was extracted using phenol chloroform method (Sambrook and Russel, 2006). DNA ( 100ng/ $\mu \mathrm{l})$ was used as template for amplification of $16 \mathrm{~S}$ rDNA region. The forward and reverse primers used were $27 \mathrm{~F}$ AGAGTTTGATCCTGGCTCAG and 1492R ACGGYTACCTTGTTACGACTT

respectively. The PCR master mix includes 1X Taq buffer, $2.5 \mathrm{mM} \mathrm{MgCl}_{2}, 0.5 \mu \mathrm{M}$ of forward and reverse primers each, $0.25 \mathrm{mM}$ dNTP mixture and $1 \mathrm{U}$ of Taq polymerase (Fermentas, USA). The PCR conditions used were as follows: $95^{\circ} \mathrm{C}$ for $5 \mathrm{~min}$ (initial denaturation); 35 cycles of $95{ }^{\circ} \mathrm{C}$ for $1 \mathrm{~min}$ (denaturation), $55^{\circ} \mathrm{C}$ for $1 \mathrm{~min}$ (annealing) and $72{ }^{\circ} \mathrm{C}$ for $1 \mathrm{~min}$ (extension) followed by final extension for $72{ }^{\circ} \mathrm{C}$ for $10 \mathrm{~min}$. The amplicons of $1500 \mathrm{bp}$ were visualized in gel documentation system (Biorad, Germany). Gel extraction kits were used for purification of amplicons (Sigma, USA) and outsourced for sequencing (Scigenome Pvt ltd, Cochin, India) and the data was analyzed with NCBI blast program. The $16 \mathrm{~S}$ rRNA gene sequences were aligned using CLUSTAL W software (Thompson et al., 1994). The phylogram was constructed using Mega 6 software (Kumar et al., 2018). Evolutionary tree was constructed using neighborhood joining method (Tamura and Nei, 1993)

\section{Results and Discussion}

The prophenoloxidase mediated melanosis distribution is organ specific viz., more in the cephalothorax and very less or nil in the pereopods (Zamorano et al., 2009). The melanized pereopods might be a result of bacteria mediated melanosis. The melanosis caused by spoilage bacteria such as Carnobacterium maltaromaticum, Shewanella purefaciens, Aeromonas salmonicida and Fusarium solanii were studied (Quin et al., 2012; Charoensapsri et al., 2014). But the bacterial associated melanosis is not elucidated in the tyrosinase producing bacterial context.

\section{Screening for tyrosinase producing bacteria}

From tyrosine agar total twenty-four colonies of distinct morphology and color formation were streaked on tyrosine agar. Among them three isolates i.e. TMA7, 9, and TMA 10 were shown zone size more than $5 \mathrm{~mm}$ with maximum production of tyrosinase enzyme with positive and negative screening (Fig. 1). The three isolates were purified and biochemically characterized (Table 1). Screening of extracellular tyrosinase was first carried out by Nurudeen and Ahearn in 1979 and recognized the importance of brown pigments in the screening of tyrosinase. Plate method for screening Streptomyces sp was established (Lemos et al., 1985) and for tyrosinase (Hagerman et al., 1985). Zone of catalysis, the positive and negative screening method (Shivaveerakumar et al., 2014) with and without tyrosine was used in the present study. The colonies namely TMA7, TMA9 and TMA 10, with brown coloration in the positive plates and without brown coloration in the negative plates were taken for biochemical characterization (Leifson, 1963). All the three colonies were non- oxidase but catalase producers. TMA7 and 10 were motile whereas TMA9 was non-motile. TMA7 was not having casein hydrolysis ability where the 
other two bacteria shown casein hydrolysis which evidences the TMA 7 is having tyrosine oxidizing capacity not the hydrolysis like Cellulophaga thyrosinoxydans isolated from seawater of eastern coast of Jeju island, Korea (Kahng et al., 2009).

Molecular identification of the tyrosinase producing bacteria by 16s rRNA sequencing analysis

16S rRNA sequencing analysis revealed that the isolates TMA7, TMA9, and TMA10 had similarity to Bacillus sp (NCBI access no MN336256), Acinetobacter sp (NCBI access no MN337281), Bacillus megaterium (NCBI access no MN337271) respectively.

The sequence of TMA 7 was compared with NCBI available sequences with the help of blast program. Blast analysis has shown 97\% identity to Bacillus niabensis. The bootstrap analysis with neighbor joining method was performed based on 1456 resampling. The closest relative strain was identified as Bacillus niabensis Marseille- $p$ strain. Identification to species level was only $97 \%$ similarity with the closely related bacterial species in the NCBI gene bank database (Fig. 1). The next closest relative is Bacillus niabensis G3-1-20 KC4 (Jonathan et al., 2014).

Blast analysis of sequenced TMA9 16s rRNA product revealed that $96 \%$ identity was shown to Acinetobacter sp. The closest strain identified was Acinetobacter jhonsonii MN307299 and Acinetobacter bouvetii strain 173 with only $96 \%$ similarity. Evolutionary tree was constructed using neighbor joining method and the phylogram was constructed using mega 6 software (Fig. 2) (Jonathen et al., 2014).

Table.1 Biochemical characteristic of tyrosinase producing bacteria

\begin{tabular}{|l|l|l|l|}
\hline Biochemical Test & \multicolumn{3}{|l|}{ Bacterial isolates } \\
& TMA7 & TMA9 & TMA10 \\
\cline { 2 - 4 } Oxidase & Negative & Negative & Negative \\
\hline Catalase & Positive & Positive & Positive \\
\hline Gram staining & $\begin{array}{l}\text { Gram positive rod } \\
\text { with spores }\end{array}$ & $\begin{array}{l}\text { Gram negative } \\
\text { diplococcic }\end{array}$ & $\begin{array}{l}\text { Gram positive rod } \\
\text { with spores }\end{array}$ \\
\hline Casein hydrolysis & Negative & Positive & Positive \\
\hline Tyrosine & Positive & Positive & Positive \\
\hline Glucose & Positive & Positive & Positive \\
\hline Mannitol & Positive & Positive & Positive \\
\hline Motility & Motile & Non-motile & Motile \\
\hline
\end{tabular}


Fig.1 Positive and negative screening method for isolation of tyrosinase producers

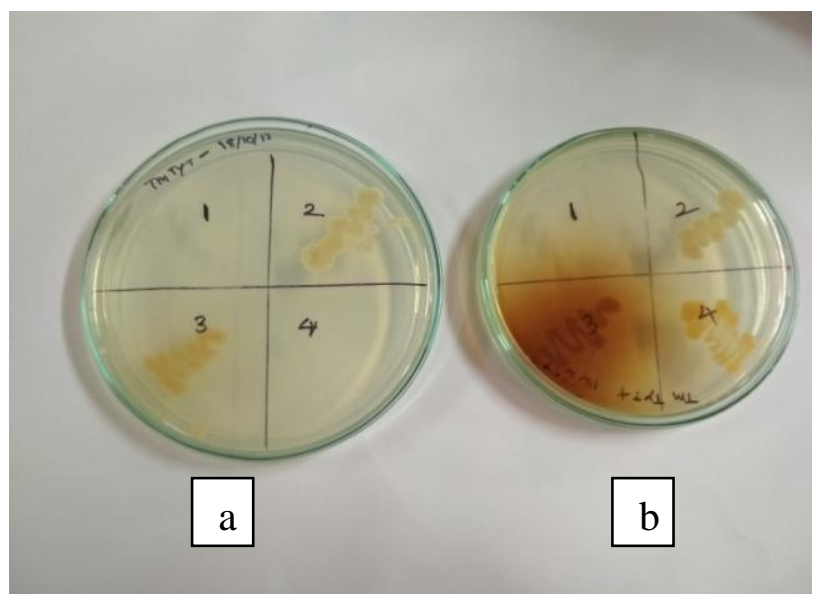

a). No discoloration of media as negative.

b). Dark brown discoloration of the media around the colonies of tyrosinase producing bacteria.

Fig.2 Phylogram of Bacillus sp TMA7]

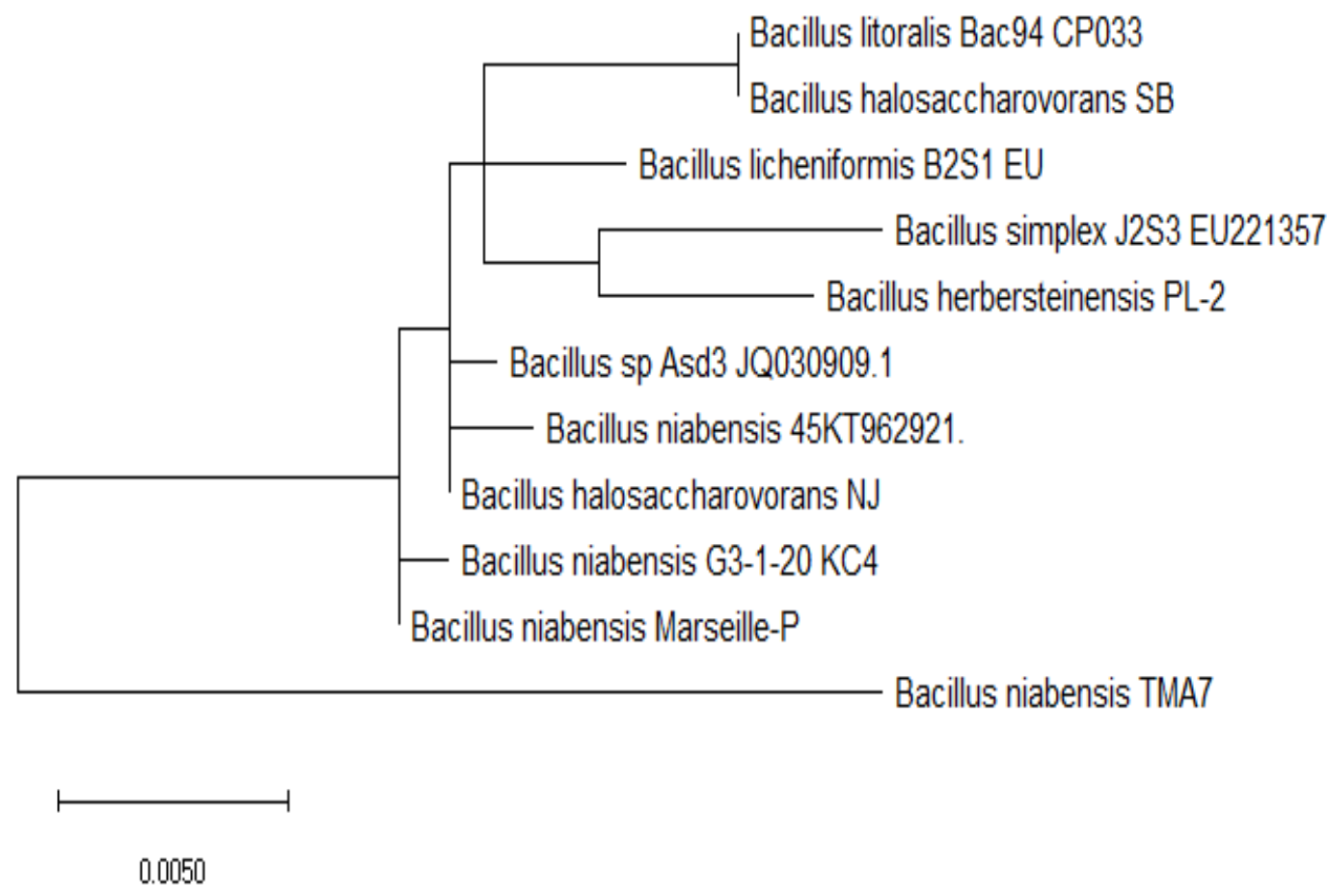


Fig.3 Phylogram of Acinetobacter sp TMA 9

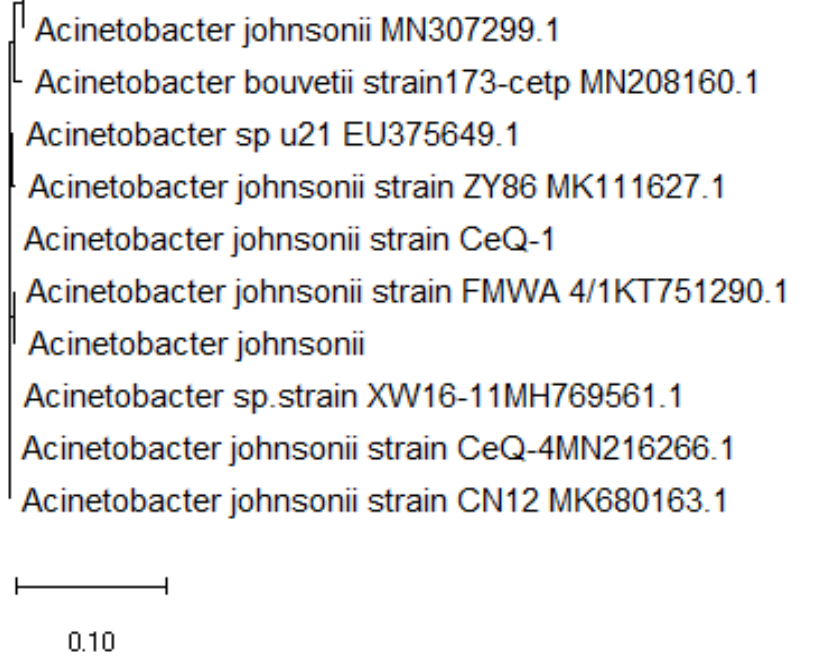

1

Fig.4 Phylogram of Bacillus megaterium

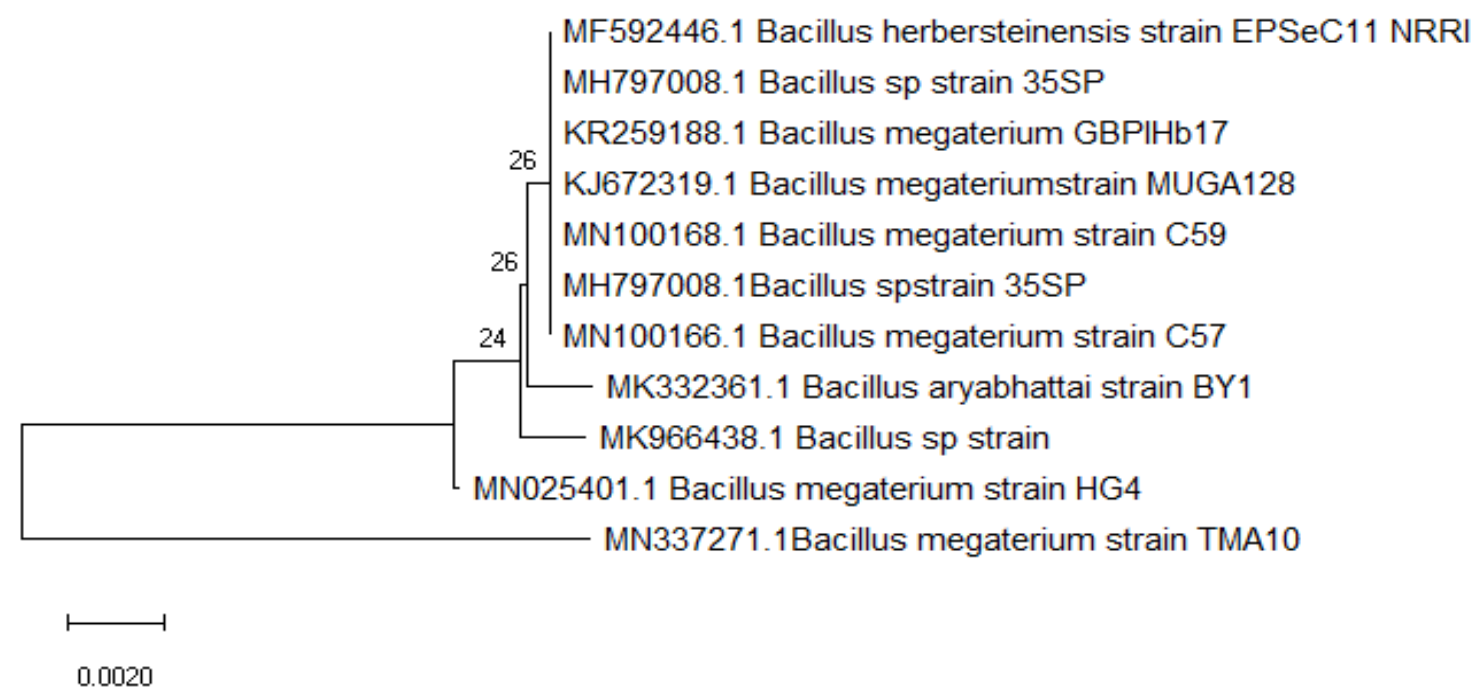

TMA 10 16S rDNA segment were amplified, sequenced using Sanger sequencing and blast analysis revealed that sequence has shown 97\% similarity to Bacillus megaterium. The closest strain identified was Bacillus megaterium strain HG4. The next closest relative is Bacillus sp MK966438.

Acinetobacter sp.strainTMA9 
and Arikan (2016) reported that Bacillus megaterium produces enzymes as per the environment requirement. Kwon et al., (2007) isolated Bacillus niabensis marseille strain from cotton waste for mushroom cultivation also reported to be tyrosine degrading. Bacillus sp isolated from Iranian soil is reported to produce cresolase, catecholase, tyrosinase and laccase (Dalford et al., 2006). The substrates used were Tyrosine, Syringaldazine and 2, 6 dimethoxy phenol. Bacillus subtilis NA2 from potato field soil of Egypt also proved to produce tyrosinase (Elsayed et al., 2018). When Bacillus sp is inoculated to shrimp sample it has reduced the tyrosine level (Cobb et al., 1971) which shows the Bacillus sp can be a potential source for tyrosine enzyme production.

The Acinetobacter sp also found to degrade various pollutants (Sun et al., 2012; Ziang et al., 2013) and phenoloxidase is also one of the characteristics in Acinetobacter calcoaceticus PFEA-2 which was isolated from phenol polluted waters of China, utilizes phenol as a sole source of carbon energy (Xu et al., 2003). Even though few studies are being carried out in the various environment for the isolation of tyrosinase producing bacteria, to the best of our knowledge this is the first reports on the association of tyrosinase producing bacteria (Bacillus sp and Acinetobacter sp) in melanized appendages of shrimp. So, these strains TMA7, TMA9 \& TMA10 belonged to (Bacillus sp and Acinetobacter sp) may be a potential candidate for bioremediation in fish processing industry in future.

The study concludes that melanized appendage of shrimp may be a good source of tyrosinase producing bacteria. Bacillus sp and Acinetobacter $\mathrm{sp}$ are the potential tyrosinase producer identified. Further studies are needed to utilize these bacteria for bioremedial applications

\section{References}

Amparyup, P., Charoensapsri, W., Tassanakajon, A., 2013. Prophenoloxidase system and its role in shrimp immune responses against major pathogens. Fish Shellfish Immunol, 34:990-1001

Cerenius, L. and Söderhäll, K., 2004. The prophenoloxidase- activating system in invertebrates. Immunological reviews, 198(1), pp.116-126.

Charoensapsri, W., Amparyup, P., Suriyachan, C. and Tassanakajon, A., 2014. Melanization reaction products of shrimp display antimicrobial properties against their major bacterial and fungal pathogens. Developmental \& Comparative Immunology, 47(1), pp.150-159.

Cobb III, B.F. and Vanderzant, C., 1971. Biochemical changes in shrimp inoculated with Pseudomonas, Bacillus and a Coryneform bacterium. Journal of Milk and Food Technology, 34(11), pp.533-547.

Dalfard, A. B., Khajeh, K., Soudi, M. R., Naderi-Manesh, H., Ranjbar, B., and Sajedi, R. H., 2006. Isolation and biochemical characterization of laccase and tyrosinase activities in a novel melanogenic soil bacterium. Enzyme Microb Technol, 39(7):1409-1416.

Decker, H., Ryan, M., Jaenicke, E., Terwilliger, N. 2001. SDS-induced phenoloxidase activity of hemocyanins from Limulus polyphemus, Eurypelma californicum and Cancer magister. J Biol Chem 276: 17796-1779

Dees, J., Momsen, J.L., Niemi, J. and Montplaisir, L., 2014. Student interpretations of phylogenetic trees in an introductory biology course. $C B E-$ Life Sciences Education, 13(4), pp.666-676

Dursewitz, G., Terwilliger, N. B. 1997. 
Developmental changes in hemocyanin expression in the Dungeness crab Cancer magister. J Biol Chem 272: 4347-4350

Elsayed, E.A., Danial, E. N. 2018. Isolation, Identification and Medium Optimization for Tyrosinase Production by a Newly Isolated Bacillus subtilis NA2 Strain. J App Pharm Sci, 8(09): 093- 101.

Gonçalves AA, de Oliveira AR. Melanosis in crustaceans: A review. LWT-Food Science and Technology. 2016 Jan 1;65:791-9.

Hagerman, A. E., Blau, D.M., and McClure, A. L. 1985. Plate assay for determining the time of production of proteases, cellulases and pectinases by germinating fungal spores. Anal. Biochem. 151(2), 334-342.

https://sciencebusiness.net/news/68164/EMPA $\% 3 \mathrm{~A}-$ Bacterial-tyrosinase-forbiomaterials: EMPA, Technology offer, Bacterial Tyrosinase for Biomaterials

Jiang, L., Ruan, Q., Li, R., Li, T. 2013. Biodegradation of phenol by using free and immobilized cells of Acinetobacter sp. BS8Y. J. Basic Microbiol. 53, 224230

Kahng, H.Y., Chung B. S., Lee D. H., Jung J. S., Park J. H., Jeon, C. O, 2009, Cellulophaga tyrosinoxydans sp. nov., a tyrosinase-producing bacterium isolated from seawater. Int J Syst Evol Microbiol 59, 654-657.

Kumar S., Stecher G., Li M., Knyaz C., and Tamura K. 2018. MEGA X: Molecular Evolutionary Genetics Analysis across computing platforms. Molecular Biology and Evolution 35: 1547-1549.

Kwon S.W., Lee S.Y., Kim B.Y., Weon, .Y., Kim J.B., Go S.J., Lee G.B. 2007. Bacillus niabensis sp. nov., isolated from cotton-waste composts for mushroom cultivation. Int J Syst Evol

\section{Microbiol 57: 1909-1913}

Leifson, E. 1963. Determination of carbohydrate metabolism of marine bacteria. J Bacteriol 85, 1183-1184.

Lemos, M.L., Toranzo, A.E. and Barja, J.L., 1985. Antibiotic activity of epiphytic bacteria isolated from intertidal seaweeds. Microbial Ecology, 11(2), pp.149-163.

Liu N, Zhang, T., Wang YJ, Huang JH, Ou P, Shen A, 2004. A heat inducible tyrosinase with distinct properties from Bacillus thuringiensis. Lett Appl Microbiol, 3: 407-412.

McMahon, A. M., Doyle, E. M., Brooks, S., and O'Connor, K. E. 2007. Biochemical characterisation of the coexisting tyrosinase and laccase in the soil bacterium Pseudomonas putida F6. Enzyme Microb. Technol. 40, 1435-1441

Nirmal, N.P., Benjakul, S., Ahmad, M., Arfat, Y.A. and Panichayupakaranant, P., 2015. Undesirable enzymatic browning in crustaceans: causative effects and its inhibition by phenolic compounds. Critical reviews in food science and nutrition, 55(14), pp.1992-2003.

Nurudeen, T.A. and Ahearn, D.G., 1979. Regulation of melanin production by Cryptococcus neoformans. Journal of clinical Microbiology, 10(5), pp.724729.

Qian, Y.F., Xie, J., Yang, S.P., Wu, W.H., Xiong, Q. and Gao, Z.L., 2014. In vivo study of spoilage bacteria on polyphenoloxidase activity and melanosis of modified atmosphere packaged Pacific white shrimp. Food chemistry, 155, pp.126-131.

Sambrook, J., and D. W. Russell, 2006. Purification of nucleic acids by extraction with phenol:chloroform. CSH Protoc. 2006: pdb.prot 4455.

Saitou N., Nei M. 1987. The neighbor-joining method: a new method for 
reconstructing phylogenetic trees. Mol Biol Evol 4: 406-425

Sanchez Amat, A., Solano, F., Lucas Elío, P. 2010. Finding New Enzymes from Bacterial Physiology: A Successful Approach Illustrated by the Detection of Novel Oxidases in Marinomonas mediterranea. Mar. Drugs, 8, 519-541

Shivaveerakumar, S., Madhusudhan, D. N., Agsar D., and M. Kontro, 2013. "Catalatyc zone, a novel screening approach for the extracellular tyrosinase by Streptomyces vinaceusdrappus DSV5," Journal of Pure and Applied Microbiology, vol. 7, no. 4, pp. 2799-2808

Söderhäll, K. and Cerenius, L., 1998. Role of the prophenoloxidase-activating system in invertebrate immunity. Current opinion in immunology, 10(1), pp. 23-28.

Sritunyalucksana, K., Cerenius, L. and Söderhäll, K., 1999. Molecular cloning and characterization of prophenoloxidase in the black tiger shrimp, Penaeus monodon. Developmental \& Comparative Immunology, 23(3), pp.179-186.

Sugumaran M. 1996. "Role of insect cuticle in immunity". In New Directions in Invertebrate Immunology. Söderhäll, K., Iwanaga, S. and Vastha, G. eds. Fair Haven, NJ. SOS Publications.. pp. 355-374.

Sugumaran, M. 1998. Unified mechanism for sclerotization of insect cuticle. Adv. Insect Physiol.; 27: 229-334.

Sun, J.Q., Xu, L.; Tang, Y.Q.; Chen, F.M.; Wu, X.L., 2012, Simultaneous degradation of phenol and nhexadecane by Acinetobacter strains. Bioresource Technol. 123, 664-668

Tamura K. and Nei M. 1993. Estimation of the number of nucleotide substitutions in the control region of mitochondrial DNA in humans and chimpanzees. Molecular Biology and Evolution 10:512-526.

Thompson, J. D. 1994. CLUSTAL W: improving the sensitivity of progressive multiple sequence alignment through sequence weighting, position-specific gap penalties and weight matrix choice. Nucleic Acids Res., 22, 4673-4680

Valipour E, Arikan B. 2016. Increased production of tyrosinase from Bacillus megaterium strain M36 by the response surface methods. Arch Biol Sci,; 68(3):659-668.

Whitaker J.R. 1995. Polyphenol Oxidase. In: Food Enzymes. Springer, Boston, MA

Xu, Y., Chen, M., Zhang, W., Lin, M. 2003. Genetic organization of genes encoding phenol hydroxylase, benzoate 1, 2-dioxygenase alpha subunit and its regulatory proteins in Acinetobacter calcoaceticus PHEA-2. Curr. Microbiol., 46, 235-240

Zamorano, J.P., Martínez-Álvarez, O., Montero, P. and del Carmen GómezGuillén, M., 2009. Characterization and tissue distribution of polyphenol oxidase of deepwater pink shrimp (Parapenaeus longirostris). Food Chemistry, 112(1), pp.104-111.

\section{How to cite this article:}

Muthulakshmi, T., U. Sivakumar, Ranjit Kumar Nadella, V. Murugadas, S.S. Greeshma and Prasad, M.M. 2019. Study on Melanized Shrimp Reveals Bacillus sp and Acinetobacter sp as Potential Sources for Bacterial Tyrosinase. Int.J.Curr.Microbiol.App.Sci. 8(12): 1430-1438. doi: https://doi.org/10.20546/ijcmas.2019.812.173 